\title{
Isolation and characterization of Salmonella enterica from Antarctic wildlife
}

\author{
Germán B. Vigo • Gerardo A. Leotta • \\ María Inés Caffer • Angela Salve · Norma Binsztein · \\ Mariana Pichel
}

Received: 17 March 2010/Revised: 29 October 2010/Accepted: 2 November 2010/Published online: 7 December 2010

(c) Springer-Verlag 2010

\begin{abstract}
In recent years, the human presence in Antarctica has increased and as a consequence, the possibility of microorganisms' introduction. The aims of this work were to determine the presence of Salmonella enterica in Antarctic seabirds and sea mammals, to characterize the isolates identified, and to determine the genetic relation of Antarctic S. enterica isolates among them and compare with isolates of human, animal, and food sources recovered in Argentina. During the summer 2000 and 2002 in Potter Peninsula, and during the summer 2001 and 2003 in Hope Bay, a total of 1,739 fecal samples from Antarctic animals were collected and analyzed. In summer 2000, $S$. Newport and $S$. Enteritidis were isolated from $8.9 \%$ of southern giant petrels (Macronectes giganteus). In summer 2003, S. Enteritidis was isolated from $1.5 \%$ of Adelie penguins (Pygoscelis adeliae), from $5.5 \%$ of skuas (Stercorarius sp.), from $5.4 \%$ of kelp gulls (Larus dominicanus), and from 5.6\% of Weddell seals
\end{abstract}

\section{G. B. Vigo $(\bowtie)$}

Cátedra de Microbiología, Facultad de Ciencias Veterinarias, Universidad Nacional de La Plata, Calle 118 y 60 cc: 296,

La Plata, Buenos Aires 1900, Argentina

e-mail: gvigo@fcv.unlp.edu.ar

\section{G. A. Leotta}

Laboratorio de Microbiología, Facultad de Ciencias Veterinarias, Universidad Nacional de La Plata, Calle 118 y 60 cc: 296,

La Plata, Buenos Aires 1900, Argentina

G. A. Leotta

Consejo Nacional de Investigaciones Científicas y Técnicas (CONICET), Buenos Aires, Argentina

M. I. Caffer · A. Salve · N. Binsztein - M. Pichel Servicio Enterobacterias, Departamento Bacteriología, Instituto Nacional de Enfermedades Infecciosas-ANLIS

“Dr. Carlos G. Malbrán”, Av. Vélez Sarsfield 563,

Buenos Aires 1281, Argentina
(Leptonychotes weddelli). All the isolates belonging to the same serovar showed indistinguishable genomic profiles by Pulse-Field Gel Electrophoresis (PFGE) with $\mathrm{Xba \textrm {I }}$ and $B \ln \mathrm{I}$ restriction enzymes and by Random Amplified Polymorphic DNA (RAPD-PCR). In addition, these Antarctic strains were different from $S$. enterica isolates from different sources identified in Argentina during the same or close time periods.

Keywords Salmonella $\cdot$ Antarctica $\cdot$ PFGE $\cdot$ RAPD-PCR

\section{Introduction}

For many years, Antarctica was a region that remained isolated from human contact. In recent years, the human presence has notably increased and as a consequence, the danger of introduction of microorganisms to the Antarctic fauna. One of these microorganisms could be Salmonella enterica, owing to its extensive distribution around the world, that could lead to the introduction through humans, as well as by carrier animals.

The introduction of diseases that can affect the Antarctic fauna has been recognized since the beginning of the Antarctic Treaty and was established as a matter of concern at the first meeting of the Biology Working Group of the Scientific Committee for Antarctic Research (SCAR) in 1962 (Murray 1964). Practical measures to diminish the risk to Antarctic wildlife of the introduction and spread of infectious diseasecausing agents by human activity have been proposed (Scientific Committee Antarctic Research-SCAR 2001).

There is little information about endemic and exotic diseases that can affect the Antarctic fauna (Leotta et al. 2006a; Nievas et al. 2007). Birds are known to be $S$. enterica carriers (Fenlon 1981; Monaghan et al. 1985; Hatch 1996; Palmgren et al. 1997) as well as seals (Gilmartin 
Table 1 Samples collected in Antarctica and analyzed for Salmonella spp. isolation, during the four periods of the study

\begin{tabular}{|c|c|c|c|c|c|}
\hline Animal species & $\begin{array}{l}\text { Summer } 2000 \\
\text { Potter Peninsula } \\
\text { No. of samples }\end{array}$ & $\begin{array}{l}\text { Summer } 2001 \\
\text { Hope Bay } \\
\text { No. of samples }\end{array}$ & $\begin{array}{l}\text { Summer } 2002 \\
\text { Potter Peninsula } \\
\text { No. of samples }\end{array}$ & $\begin{array}{l}\text { Summer } 2003 \\
\text { Hope Bay } \\
\text { No. of samples }\end{array}$ & Total No. of samples \\
\hline Adelie penguins & 50 & 751 & - & 132 & 933 \\
\hline Gentoo penguins & 50 & 100 & 31 & 35 & 216 \\
\hline Skuas & 66 & 14 & 34 & 36 & 150 \\
\hline Southern giant petrels & 90 & - & 49 & - & 139 \\
\hline Kelp gulls & - & 50 & - & 56 & 106 \\
\hline Snowy sheathbills & - & 50 & 6 & 23 & 79 \\
\hline Chinstrap penguins & - & - & 40 & - & 40 \\
\hline Wedell seals & - & - & - & 71 & 71 \\
\hline Antarctic fur seals & - & - & - & 5 & 5 \\
\hline Total & 256 & 965 & 160 & 358 & 1739 \\
\hline
\end{tabular}

et al. 1979; Thornton et al. 1998; Smith et al. 2002; Fenwick et al. 2004). Antarctic birds and seals have exhibited symptoms of a variety of infectious diseases, indicating that they are susceptible to a range of pathogens (SCAR 2001; Leotta et al. 2006a; Nievas et al. 2007).

The Hope Bay area, located at the tip of the Antarctic Peninsula, encompasses Hope Base, the northernmost continental Antarctic Station $\left(63^{\circ} 24^{\prime} \mathrm{S}, 56^{\circ} 59^{\prime} \mathrm{W}\right)$. During spring and summer seasons, Adelie penguins (Pygoscelis adeliae), gentoo penguins (Pygoscelis papua), kelp gulls (Larus dominicanus), brown skuas (Stercorarius Antarctica lonnbergi), snowy sheathbills (Chionis albus), Antarctic terns (Sterna vittata), and Wilson's storm petrels (Oceanites oceanicus) breed in Hope Bay (Leotta et al. 2006a). In the Potter Peninsula, King George Island, and South Shetland Islands $\left(62^{\circ} 15^{\prime}, 58^{\circ} 36^{\prime} \mathrm{W}\right)$ during spring and summer seasons, Adelie penguins, gentoo penguins, chinstrap penguins (Pygoscelis antartica), kelp gulls, brown skuas, south polar skuas, southern giant petrels (Macronectes giganteus), snowy sheathbills, cape petrel (Daption capense), Antarctic terns, black-bellied storm petrel (Fregetta tropica), Wilson's storm petrels, and imperial cormorant (Phalacrocorax atriceps) breed into the area (Hahn et al. 1998). In addition, in both areas, there are occasional findings of settlement of Antarctic fur seals (Arctocephalus gazella), crabeater seals (Lobodon carcinophagus), leopard seals (Hidrurga leptonix), Weddell seals (Leptonychotes weddelli), and southern elephant seals (Mirounga leonina). In Potter Peninsula, a reproductive colony of southern elephant seals is settled.

The aims of this work were to determine the presence of $S$. enterica in Antarctic seabirds and sea mammals, to characterize the isolates identified, and to determine the genetic relation of Antarctic S. enterica isolates among them and compare with isolates of human, animal, and food sources recovered in Argentina.

\section{Methods}

During 2000 and 2002 breeding seasons in Potter Peninsula, and during 2001 and 2003 breeding seasons in Hope Bay, samples from seabirds and sea mammals were collected. Breeding areas from skuas, kelp gulls, south giant petrels, Adelie penguins, gentoo penguins, chinstrap penguins, and snowy sheathbills were identified. The population census by Hahn et al. (1998) and Leotta et al. (2006a) were considered for sampling. In addition, occasionally settling Antarctic fur seals and Weddell seals were sampled. A total of 1,739 fecal samples from Antarctic animals were collected and analyzed for $S$. enterica isolation. The animals sampled during the four campaigns are showed in Table 1. A non-probabilistic sampling by convenience was carried out among all animals that were kept momentarily apart for different biological studies.

A total of 1,663 seabirds were captured, clinically evaluated by experienced veterinarians and sampled by cloacal swabs, which were kept in Stuart transport media (Difco Laboratories Incorporated, Cambridge, UK). In addition, 76 Antarctic fur seals and Weddell seals were observed but not captured, and immediately after defecation an aliquot of fresh feces was collected in sterile bags (Nasco's Whirl-pak, Network International Technologies, Buenos Aires, Argentina). All samples were processed between 1 and $4 \mathrm{~h}$ after collection. Samples were inoculated in selenite broth (Becton-Dickinson and Company Spark, Baltimore, USA) and incubated for $24 \mathrm{~h}$ at $37^{\circ} \mathrm{C}$ (enrichment). A loopful of enrichment broth was transferred to enteric Hektoen agar (Becton-Dickinson) and incubated for $24-48 \mathrm{~h}$ at $37^{\circ} \mathrm{C}$. Two presumptive Salmonella colonies were streaked in trypticase soy agar (Becton-Dickinson), incubated for $24 \mathrm{~h}$ at $37^{\circ} \mathrm{C}$ and were subsequently confirmed by biochemical conventional assays (Koneman et al. 1999). Isolates identified as $S$. enterica were serotyped by agglutination according 
to M. Poppö̈s scheme (Poppof et al. 1990) using specific antisera produced by the Servicio Antígenos y Antisueros, Instituto Nacional de Producción de Biológicos-ANLIS "Carlos G. Malbrán”. Susceptibility of Antarctic S. enterica strains to antimicrobial agents was established by disk diffusion according to the Clinical Laboratory Standards Institute (CLSI 2007). All the disks used in this assay (ciprofloxacin, tetracycline, gentamicin, nitrofurantoin, ampicillin, cefotaxime, trimethoprim-sulphamethoxazole, nalidixic acid, polimixin, fosfomycin, and chloramphenicol were from Laboratorios Britania, Buenos Aires, Argentina, except for streptomycin that was from Oxoid, Hampshire, England.

Pulsed-Field Gel Electrophoresis (PFGE) was carried out following PulseNet standardized protocol for Salmonella from the Centers for Disease Control and Prevention (CDC 2004). Briefly, the agarose plugs containing DNA were digested overnight with $30 \mathrm{U}$ of $\mathrm{Xba \textrm {I }}$ (Promega, Madison, Wisconsin, USA). DNA fragments were separated in $1 \%$ agarose gels (Seakem Gold, Lonza, Rockeland, ME, USA) in 0.5\% tris-borate-EDTA buffer at $14^{\circ} \mathrm{C}$ in a contour CHEF DR III System (Bio-Rad, Hercules, California, USA). Run time was $22 \mathrm{~h}$, with a constant voltage of $200 \mathrm{~V}$, using linear ramp of 2.2-54.2 s. Staining was carried out with $0.5 \mathrm{ug} / \mathrm{ml}$ of aqueous ethidium bromide solution (Bio-Rad). The DNA of selected Antarctic isolates showing identical PFGE profiles with $X b a \mathrm{I}$ were also digested with $30 \mathrm{U}$ of $B \ln \mathrm{I}$ (Promega). PulseNet standard strain S. Braenderup CDC-H-9812 was included as fragment size marker to analyze the patterns generated with $X b a \mathrm{I}$ and $B \ln \mathrm{I}$. Random Amplified Polymorphic DNA (RAPD-PCR) was carried out essentially as described by Pacheco et al. (1996). From a pure bacterial culture grown in trypticase soy agar (Laboratorios Britania), 3-4 colonies were inoculated in $3 \mathrm{ml}$ of trypticase soy broth (Laboratorios Britania), incubated at $37^{\circ} \mathrm{C}$ for $24 \mathrm{~h}$. Then, optical density (OD) of the cell suspension was adjusted to 0.4 at $600 \mathrm{~nm}$ of wavelength. Bacterial suspensions were boiled for $10 \mathrm{~m}$, cooled and centrifuged for $20 \mathrm{~s}$ at $10,000 \mathrm{rpm}$. Supernatants were used as DNA templates. The electrophoresis was carried out in a $2 \%$ agarose gel (Bio-Rad) in $1 \times$ tris acetic EDTA, applying $70 \mathrm{~V}$ during $95 \mathrm{~m}$. The molecular weight marker was 1-kb DNA ladder (Promega). Gel staining was carried out with $0.5 \mathrm{ug} / \mathrm{ml}$ of aqueous ethidium bromide solution (Bio-Rad).

The images of PFGE and RAPD-PCR fingerprints were obtained by Gel-doc system (Bio-Rad) and were analyzed using BioNumerics software version 3.5 (Applied Maths, Kortrijk, Belgium). The relationship among the patterns was estimated by the proportions of shared bands applying the DICE coefficient with a $1.5 \%$ band position tolerance, and a dendrogram based on the Unweight Pair Group
Method with Arithmetic Averages (UPGMA) method was generated.

Salmonella enterica isolated from Antarctica were compared with isolates circulating in Argentina, $18 \mathrm{~S}$. Newport and $19 \mathrm{~S}$. Enteritidis isolates selected from the culture collection of Servicio Enterobacterias, Departamento Bacteriología, INEI-ANLIS “Dr. Carlos G. Malbrán” and Laboratorio de Diagnóstico e Investigaciones Bacteriológicas, Facultad de Ciencias Veterinarias, Universidad Nacional de La Plata. The isolates from Argentina were recovered in different regions of the country from human, animal, and food sources during the same or a close time period of Antarctic samplings. A total of 56 isolates were analyzed, including 25 $S$. Newport and $31 S$. Enteriridis strains.

\section{Results}

Nineteen $S$. enterica isolates were recovered during 2000-2003 period: eleven were identified as $S$. Enteritidis and eight as $S$. Newport. In summer 2000 in Potter Peninsula, seven $S$. Newport and one $S$. Enteritidis were isolated from southern giant petrels (8.9\%). In summer 2003, in Hope Bay, eleven $S$. Enteritidis were isolated from two Adelie penguins (1.5\%), two skuas (5.5\%), three kelp gulls $(5.4 \%)$, and four Weddell seals $(5.6 \%)$. The animals sampled in summer 2001 in Hope Bay and in summer 2002 in Potter Peninsula were negative for Salmonella spp. Tables 1 and 2 show seabirds and sea mammals sampled, the number of samples processed, S. enterica serovars identified, places and years of sampling.

All the Antarctic $S$. Enteritidis and $S$. Newport isolates analyzed were susceptible to all the antimicrobial agents tested.

All Antarctic $S$. Newport isolates showed the same PFGE profile with the restriction enzyme $X b a \mathrm{I}$. This profile included 13 DNA fragments with molecular weight between 20.5 and $1,100 \mathrm{~Kb}$. Comparing the Antarctic $S$. Newport $X b a \mathrm{I}$-PFGE pattern with $S$. Newport $X b a \mathrm{I}$-PFGE patterns from Argentina, between 2 and 7 different bands were found (Fig. 1). Likewise, all Antarctic $S$. Enteritidis isolates showed the same PFGE profile with the restriction enzyme XbaI. This profile comprised 12 DNA fragments with molecular weight between 20.5 and 1,000 Kb. The Antarctic $S$. Enteritidis XbaI-PFGE pattern showed between 3 and 7 different bands, compared to $S$. Enteritidis XbaI-PFGE patterns from Argentina (Fig. 2). To confirm that the Antarctic isolates showed identical genetic profiles, PFGE using $B \ln \mathrm{I}$ restriction enzyme and RAPD-PCR were performed. Both $S$. Enteritidis and $S$. Newport showed the same profile by $B \ln \mathrm{I}-\mathrm{PFGE}$ within each serovar (data not showed). Both, $S$. Enteritidis and $S$. Newport showed the 
Table 2 Seabirds and sea mammals species positive for Salmonella spp., serovars identified, places, and years of sampling

\begin{tabular}{|c|c|c|c|c|c|c|}
\hline \multirow[t]{2}{*}{ Species } & \multicolumn{3}{|c|}{ Samples } & \multirow[t]{2}{*}{ Serovars } & \multirow[t]{2}{*}{ Places } & \multirow[t]{2}{*}{ Year } \\
\hline & $N$ & Positive & $\%$ & & & \\
\hline Southern giant petrel & 90 & 8 & 8.9 & $\begin{array}{l}S . \text { Newport (n:7) } \\
S . \text { Enteritidis (n:1) }\end{array}$ & Potter Peninsula & 2000 \\
\hline Adelie penguin & 132 & 2 & 1.5 & $S$. Enteritidis & Hope Bay & 2003 \\
\hline Skua & 36 & 2 & 5.5 & $S$. Enteritidis & Hope Bay & 2003 \\
\hline Kelp gull & 56 & 3 & 5.4 & $S$. Enteritidis & Hope Bay & 2003 \\
\hline Weddell seal & 71 & 4 & 5.6 & $S$. Enteritidis & Hope Bay & 2003 \\
\hline Total & 385 & 19 & & & & \\
\hline
\end{tabular}

Fig. 1 PFGE dendrogram showing the genetic relation between the isolates of Salmonella Newport from Antarctica and sporadic isolates from different sources (human, animal, and food)

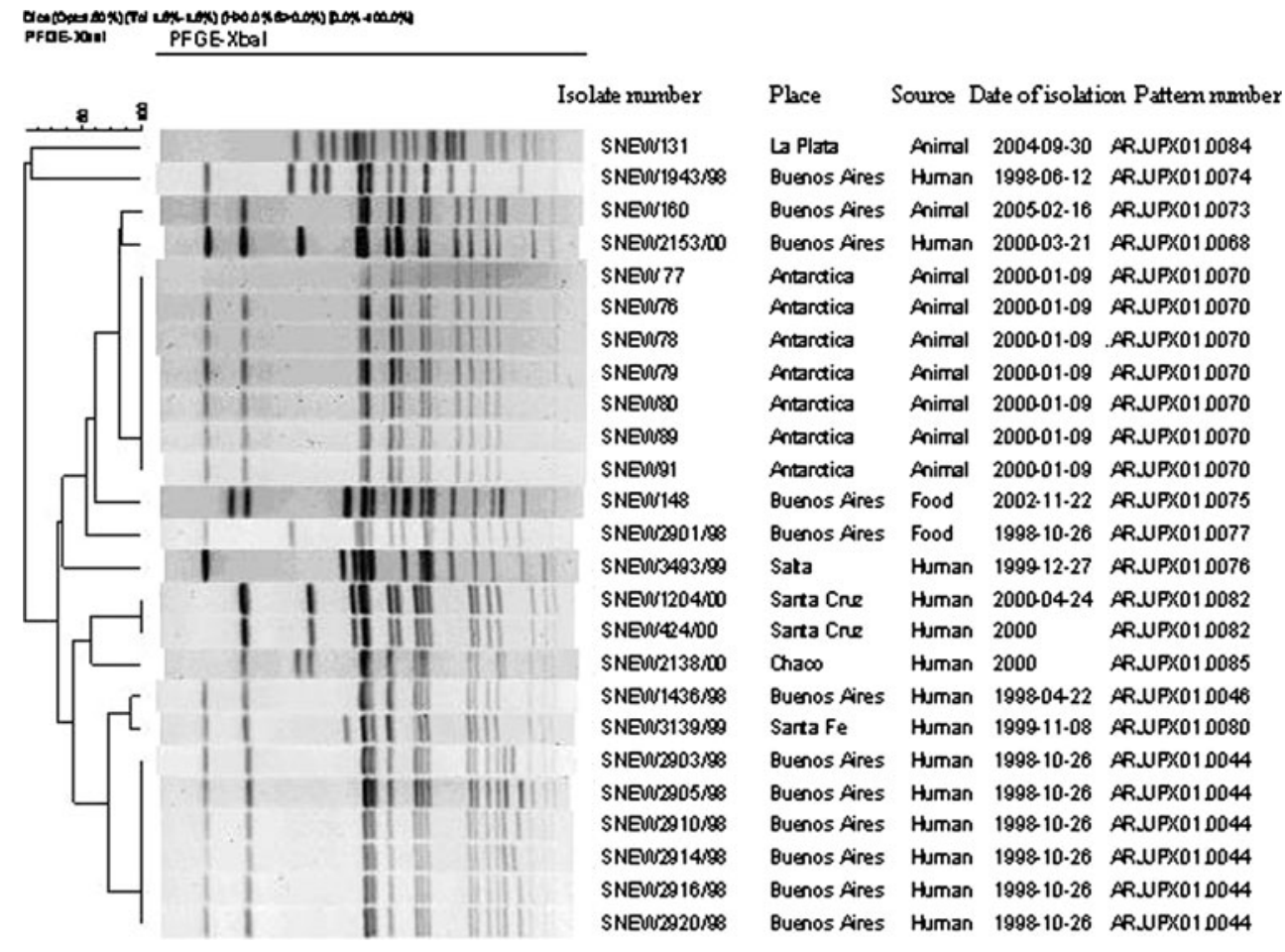

same profile by RAPD-PCR within each serovar with 7 and 6 DNA fragments, respectively (Fig. 3).

\section{Discussion}

Antarctica is the last continent to receive some considerations to limit the human activity and avoid introducing pathogen microorganisms to Antarctic animals. There are no measures planned to limit the dissemination of diseases in case of infectious outbreaks. Furthermore, there is evidence that introduced diseases can cause the declination of autochthonous population. One example frequently cited is the effect caused by the introduction of avian smallpox and avian malaria in Hawaiian birds (Warner 1968; Van Riper et al. 1986).
Several studies have been carried out in the Antarctic fauna with the purpose of assessing $S$. enterica presence. Between 1957 and 1996 in the Antarctic region, samples were taken from different animals, penguin species, skuas, seals, and the following serovars of Salmonella enterica were identified, S. blockey, S. johannesburg, S. typhimurium, S. panama, and S. infantis (Soucek and Mushin 1970; Oelke and Steiniger 1973; Sieburth 1979). In 1995-1996, $S$. Enteritidis was isolated from gentoo penguins at Bird Island, South Georgia, and sub-Antarctica (Olsen et al. 1996). In addition, in sub-Antarctica S. havana, S. Enteritidis, and $S$. Newport were isolated from gentoo penguins, black-browed albatrosses (Diodema melanophrys), and Antarctic fur seals (Palmgren et al. 2000). In the present study, $S$. Newport was isolated from southern giant petrels, and $S$. Enteritidis was isolated from Adelie penguins, 
Fig. 2 PFGE-Dendogram showing the genetic relation between the isolates of Salmonella Enteritidis from Antarctica and sporadic isolates from different sources (human and animal)
Fig. 3 RAPD-PCR dendogram showing the genetic relation between the isolates of Salmonella Newport and Salmonella Enteritidis recovered in Antarctica

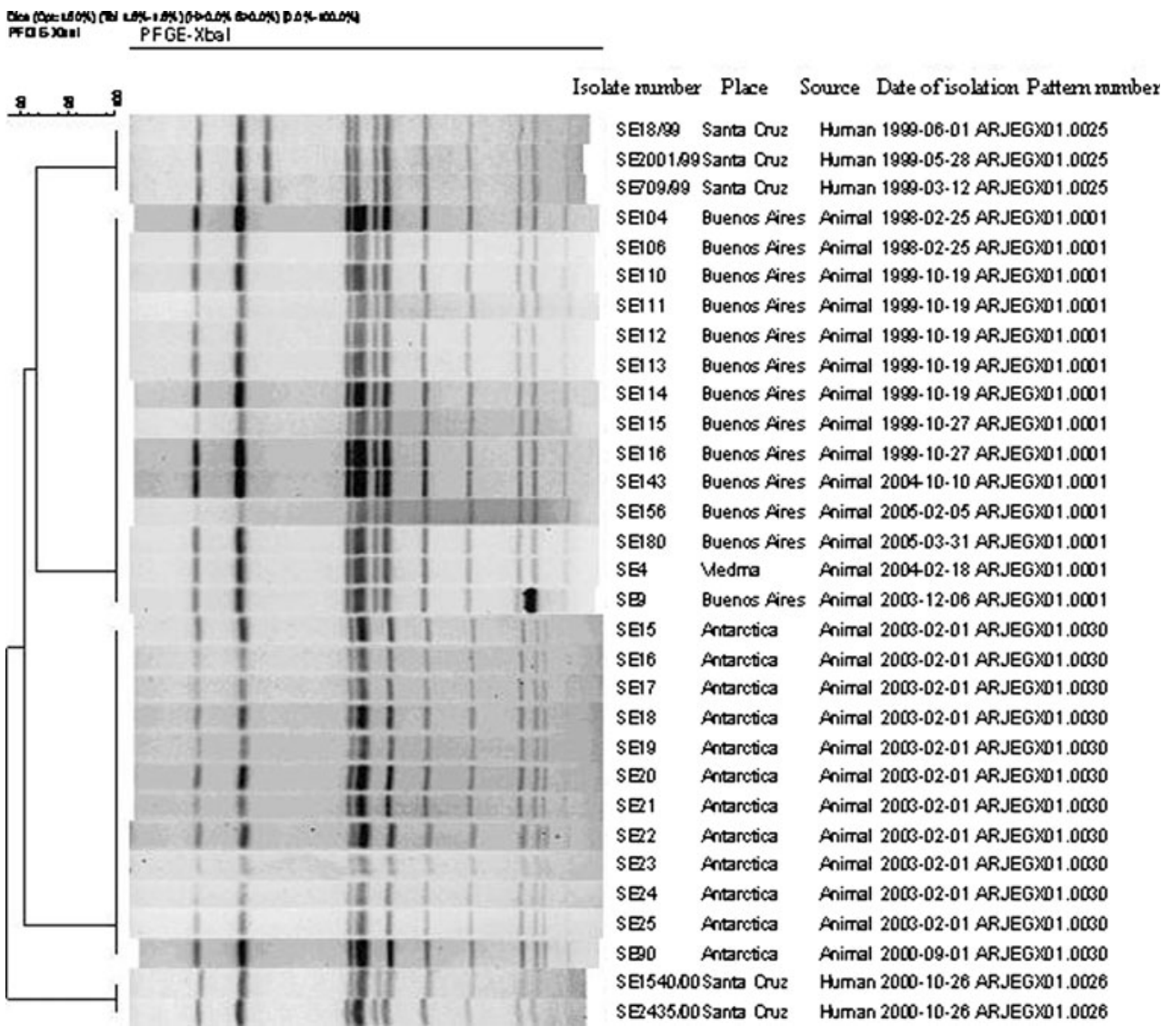

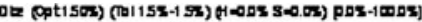
RAPD 100 to RAPD 100 bp

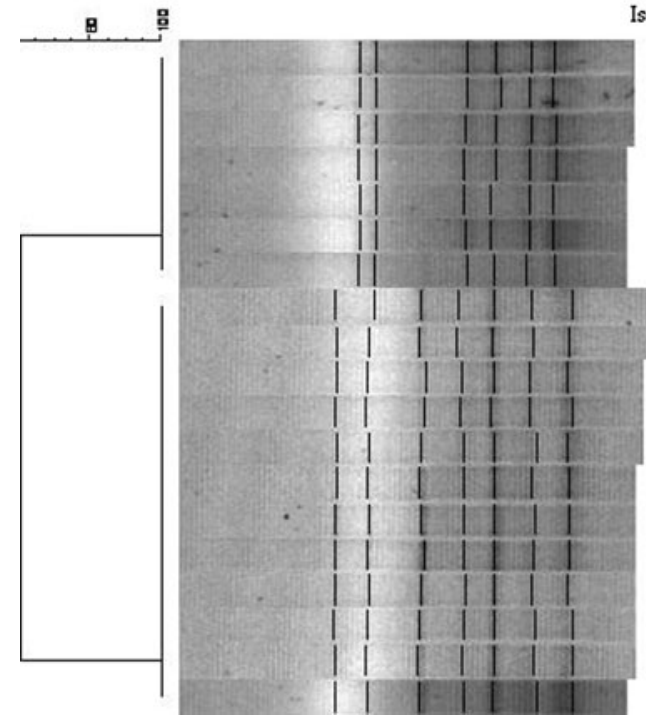

\begin{tabular}{|c|c|c|c|c|}
\hline olate number & Date of isolation & Source & number & Serovar \\
\hline SNEW 76 & $9-1-2000$ & ...Petrel & 3 & Newport \\
\hline SNEW 77 & $9.1-2000$ & ...Petrel & 3 & Newport \\
\hline SNEW 78 & $9-1-2000$ & ...Petrel & 3 & Newport \\
\hline SNEW 79 & 9.1-2000 & ...Petrel & 3 & Newport \\
\hline SNEW 80 & $91-2000$ & ...Petrel & 3 & Newport \\
\hline SNEW 89 & 9-1-2000 & ...Petrel & 3 & Newport \\
\hline SNEW 91 & $9.1-2000$ & ...Petrel & 3 & Newport \\
\hline SE 15 & $2-1-2003$ & ...Weddell Seal & 1 & Enteritidis \\
\hline SE 16 & $2-1-2003$ & ... Weddell Seal & 1 & Enteritidis \\
\hline SE 17 & 2-1-2003 & ...Kelp gull & 1 & Enteritidis \\
\hline SE 18 & $2-1-2003$ & ...Skua & 1 & Enteritidis \\
\hline SE 19 & 2-1.2003 & ... Weddell Seal & 1 & Enteritidis \\
\hline SE 20 & 2-1-2003 & ...Kelp gull & 1 & Enteritidis \\
\hline SE 21 & $2-1-2003$ & ...Weddell Seal & 1 & Enteritidis \\
\hline SE 22 & $2-1-2003$ & ...Adelle penguin & 1 & Enteritidis \\
\hline SE 23 & $2-1-2003$ & ...Kelp gull & 1 & Enteritidis \\
\hline SE 24 & $2 \cdot 1-2003$ & ...Adelle penguin & 1 & Enteritidis \\
\hline SE 25 & $2-1-2003$ & ...Skua & 1 & Enteritidis \\
\hline SE 90 & $9-1.2000$ & ...Petrel & 1 & Enteritidis \\
\hline
\end{tabular}

skuas, kelp gulls, and Weddell seals. This is the first time that $S$. enterica was isolated from southern giant petrel, kelp gulls, and Weddell seals in the Antarctic region. In conclusion, very few $S$. enterica serovars appear to be circulating in the Antarctic area. If the bacterium is endemic in the region or was recently introduced is a question without answer yet.

$S$. Newport and $S$. Enteritidis are human pathogens, especially the latter serovar that is one of the most common causes of human salmonellosis (Rodrigue et al. 1990; Le 
Bacq et al. 1994). S. Newport was reported to cause disease in captive penguins (Cockburn 1947). Also, it is commonly isolated from seals without signs of salmonellosis and from ill animals (Gilmartin et al. 1979; Baker et al. 1995), and it is endemic in pinnipeds according to studies performed in the sub-Antarctic region and other places (Fenwick et al. 2004). None of the animals sampled in this study showed clinical signs of salmonellosis, so apparently, the studied Antarctic animals would be the healthy carriers.

One of the most possible routes of introduction of S. enterica to Antarctica is by migratory birds (Olsen et al. 1996). Many of Antarctic birds have long routes of migration, and along their routes, they pass over waste disposal tips, polluted rivers and lakes, and fields manured with feces; therefore, in these places, they could acquire the microorganism. Unfortunately, neither in this study nor in other previous investigations performed in the Antarctic region was it possible to determine the source of the bacterium.

In recent years, studies on antimicrobial resistance of S. enterica from different sources (human, animal, feed and environment) were carried out, and owing to the antimicrobial misuse and abuse, S. enterica resistant strains are being frequently found around the world (Levy et al. 1988; Poppe et al. 2001; Molla et al. 2006). All Antarctic isolates from this study were susceptible to all the antimicrobial agents tested. This would indicate that Antarctic isolates were not exposed to antimicrobial selection pressure and neither acquired resistance from other microorganisms circulating in the Antarctic ecosystem.

There is scarce knowledge about $S$. enterica epidemiology in Antarctic animals. To define control strategies, it is essential to know about the biological cycle of infectious agents. For that, it is necessary to investigate the reservoirs and transmission ways, as well as the ecological conditions that allow the pathogen's survival. In addition, very few studies including the analysis of Salmonella enterica using molecular epidemiology were carried out in Antarctica. In the present study, $S$. Newport was only isolated from southern giant petrels in summer 2000 in Potter Peninsula, and all isolates showed an identical genomic profile by PFGE and RAPD-PCR. Therefore, the infections were caused by the same $S$. Newport subtype. Unfortunately, we could not determine whether the pathogen was transmitted from bird to bird or was acquired from exposure to the same infection source. $S$. Enteritidis was isolated from one southern giant petrel in summer 2000 in Potter Peninsula, and in summer 2003 in Hope Bay, the pathogen was isolated from three different bird species and from Weddell seals; all the isolates showed an identical genomic profile by PFGE and RAPD-PCR. Therefore, the infection was caused by the same $S$. Enteritidis subtype. Unfortunately, we could not determine whether the pathogen persisted in Antarctic animals or in the Antarctic environment.

Comparing the results obtained by PFGE of Antarctic $S$. Newport and $S$. Enteritidis within each serovar with the isolates from Argentina, we concluded that there is no relationship among them.

There are few reports of molecular epidemiology carried out with bacteria isolated from Antarctica: Pasteurella multocida subspecies gallicida type A:1 isolates were associated with two avian cholera outbreaks occurred with a difference of 1 year, and all strains showed identical genomic profiles by PFGE (Leotta et al. 2006a). In this study, $S$. Newport and $S$. Enteritidis showed identical genomic profile by PFGE and RAPD-PCR within each serovar. Therefore, this could be indicating that these Antarctic bacteria were either subjected to low pressure from the environment or recently introduced to the area.

We demonstrated previously that Antarctic seabirds carried bacterial pathogens in their intestines (Leotta et al. 2006b). Human activity in Antarctica has been identified as a possible source of infectious agents (SCAR 2001). Birds carrying $S$. Newport and $S$. Enteritidis in their guts settled around lakes which are used to supply with fresh water for human; therefore, this could be a possible way of S. enterica transmission to the inhabitants. However, to our knowledge, there are no reports about zoonotic enteropathogens causing diseases in humans that live in the Antarctic region. S. enterica epidemiology in the Antarctic fauna and its possible transmission to humans and vice versa needs to be further investigated.

Acknowledgments The authors would like to thank Instituto Antártico Argentino and Departamento de Biología, Dirección Nacional del Antártico, for providing support for field work in Antarctica, especially to N. R. Coria. We are grateful to M. Pérez Cometto and D. Montalti for their field collaboration.

\section{References}

Baker J, Hall A, Hiby L, Munro R, Robinson I, Ross H, Watkins J (1995) Isolation of Salmonellae from seals from UK waters. Vet Rec 136:471-472

Center for Disease Control and Prevention (2004) Standardized molecular subtyping of foodborne bacterial pathogens by pulsefield gel electrophoresis. Pulse-Net The National Molecular Subtyping Network for Foodborne Disease Surveillance, Atlanta, GA

Clinical and Laboratory Standards Institute (2007) Performance standards for antimicrobial susceptibility testing, 17th Informational Supplement, M100-S17, 27(1), 32-37. CLSI, Wayne, PA

Cockburn T (1947) Salmonella Typhimurium in penguins. J Comp 57:77-78

Fenlon DR (1981) Seagulls (Larus spp.) as vectors of Salmonellae: an investigation into the range of serotypes and numbers of Salmonellae in gull faeces. J Hyg 86:195-202 
Fenwick SG, Duignan PJ, Nicol CM, Leyland MJ, Hunter JEB (2004) Comparison of Salmonella serotypes isolated from New Zealand sea lions and feral pigs on the Auckland Islands by Pulse-Field Gel Electrophoresis. J Wild Dis 40:566-570

Gilmartin WG, Vainik PM, Neill VM (1979) Salmonellae in feral pinnipeds off the southern Californian coast. J Wild Dis 15:511-514

Hahn S, Peter HU, Quillfedt P, Reinhardt K (1998) The birds of the Potter Peninsula, King George Island, South Shetland Islands, Antarctica, 1965-1998. Mar Orn 26:1-6

Hatch J (1996) Threats to public health from gulls (Laridae). Int J Environ Health Res 6:5-16

Koneman EW, Allen SD, Janda WM, Schreckenberg PC, Winn WC (1999) Enterobacteriaceae. In: Koneman EW (ed) Diagnóstico microbiológico, 5th edn. Editorial médica panamericana, Buenos Aires, Argentina, pp 171-250

Le Bacq F, Louwagie B, Verhaegen J (1994) Salmonella Typhimurium and Salmonella Enteritidis: changing epidemiology from 1973-1992. Eur J Epidemiol 10:367-371

Leotta GA, Chinen I, Vigo G, Pecoraro M, Rivas M (2006a) Outbreaks of avian cholera in Hope Bay, Antarctica. J Wild Dis 42:259-270

Leotta GA, Vigo GB, Giacoboni G (2006b) Isolation of Campylobacter lari from seabirds in Hope Bay, Antarctica. Polish Polar Res 27:303-308

Levy S, Marshall B, Schluederberg S, Rowse D, Davis J (1988) High frequency of antimicrobial resistance in human fecal flora. Antimicrob Agents Chemoter 32:1801-1806

Molla B, Berhanu A, Muckle A, Cole L, Wickie E, Kleer J, Hildebrandt $\mathrm{G}$ (2006) Multidrug resistance and distribution of Salmonella serovars in slaughtered pigs. J Vet Med B 53:28-33

Monaghan P, Shedden C, Ensor K, Fricker C, Girwood R (1985) Salmonella carriage by herring gulls in the Clyde area of Scotland in relation to their feeding ecology. J Appl Ecol 22:669-680

Murray MD (1964) Ecology of the ectoparasites of seals and penguins. In: Carrick R, Holdgate M, Prevost J (eds) Biologie antarctique: premier symposium organise par le SCAR. Hermann, Paris, France, pp 241-245

Nievas VF, Leotta GA, Vigo GB (2007) Subcutaneous clostridial infection in Adelie penguins in Hope Bay, Antarctica. Polar Biol 30:249-252

Oelke H, Steiniger F (1973) Salmonella in Adelie penguins (Pygoscelis adeliae) and south polar skuas (Catharacta maccormicki) on Ross Island, Antarctica. Avian Dis 17:568-573
Olsen B, Bergström S, McCafferty D, Sellin M, Wiström J (1996) Salmonella enteritidis in Antarctica: zoonosis in man or humanosis in penguins? Lancet 348:1319-1320

Pacheco ABF, Guth BEC, de Almeida DF, Ferreira LCS (1996) Characterization of enterotoxigenic Escherichia coli by random amplification of polymorphic DNA. Res Microbiol 147:175-182

Palmgren H, Sellin M, Bergström S, Olsen B (1997) Enteropathogenic bacteria in migrating birds arriving in Sweden. Scand $\mathrm{J}$ Infect Dis 29:565-568

Palmgren H, McCafferty D, Aspán A, Broman T, Sellin M, Wollin R, Bergström S, Olsen B (2000) Salmonella in sub-Antarctica: low heterogeneity in Salmonella serotypes in South Georgian seals and birds. Epidemiol Infect 125:257-262

Poppe C, Ayroud M, Ollis G, Chirino-Treso M, Smart N, Quessy S, Michel P (2001) Trends in antimicrobial resistance of Salmonella isolated from animals, foods of animal origin and the environment of animal production in Canada 1994-1997. Microb Drug Resist 7:197-212

Poppof M, Bockemuhl J, McWorther-Murlin A (1990) Supplement 1990 (no 34) to the Kauffman-White scheme. Res Microbiol Inst Pasteur 142:1029-1033

Rodrigue DC, Tauxe R, Rowe B (1990) International increase in Salmonella enteritidis: a new pandemic? Epidemiol Infect 105:21-27

Scientific Committee Antarctic Research (2001) Report on the opened-ended Intersessional Contact on Diseases of Antarctic Wildlife. IV CEP Working Paper WP-11 Agenda Item 4d, Australia. http://www.cep.aq

Sieburth J (1979) Gastrointestinal microflora of Antarctic birds. J Bacteriol 15:511-514

Smith WA, Mazet JA, Hirsh DC (2002) Salmonella in California wildlife species: prevalence in rehabilitation centers and characterization of isolates. J Zoo Wildl Med 33:228-235

Soucek Z, Mushin R (1970) Gastrointestinal bacteria of certain Antarctic birds and mammals. Appl Microbiol 20:561-566

Thornton SM, Nolan S, Gulland F (1998) Bacterial isolates from California sea lions (Zalophus californianus), and northern elephant seals (Mirounga angustirostris) admitted to a rehabilitation center along the central California coast, 1994-1995. J Zoo Wildl Med 29:171-176

Van Riper CI, Goff ML, Laird M (1986) The epizootiology and ecological significance of Malaria in Hawaiian land birds. Ecol Monogr 56:327-344

Warner RE (1968) The role of introduced diseases in the extinction of endemic Hawaiian avifauna. Condor 70:101-120 